\title{
A SHORT COURSE IN SOIL-STRUCTURE ENGINEERING \\ OF DEEP FOUNDATIONS, EXCAVATIONS AND TUNNELS
}

CHARLES W. W. NG, NOEL SIMONS and BRUCE MENZIES

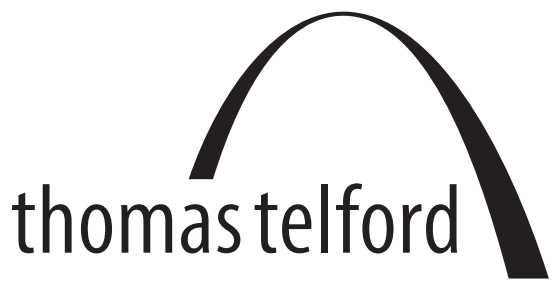


Published by Thomas Telford Publishing, Thomas Telford Ltd, 1 Heron Quay, London E14 4JD.

www.thomastelford.com

Distributors for Thomas Telford books are

USA: ASCE Press, 1801 Alexander Bell Drive, Reston, VA 20191-4400, USA

Japan: Maruzen Co. Ltd, Book Department, 3-10 Nihonbashi 2-chome, Chuo-ku, Tokyo 103

Australia: DA Books and Journals, 648 Whitehorse Road, Mitcham 3132, Victoria

First published 2004

Reprinted 2006

Reprinted with corrections 2008

A catalogue record for this book is available from the British Library

ISBN: 0727732633

ISBN: 9780727732633

(C) Charles Ng, Noel Simons, Bruce Menzies and Thomas Telford Limited 2004.

All rights, including translation, reserved. Except as permitted by the Copyright, Designs and Patents Act 1988, no part of this publication may be reproduced, stored in a retrieval system or transmitted in any form or by any means, electronic, mechanical, photocopying or otherwise, without the prior written permission of the Publishing Director, Thomas Telford Publishing, Thomas Telford Ltd, 1 Heron Quay, London E14 4JD.

This book is published on the understanding that the authors are solely responsible for the statements made and opinions expressed in it and that its publication does not necessarily imply that such statements and/or opinions are or reflect the views or opinions of the publishers. While every effort has been made to ensure that the statements made and the opinions expressed in this publication provide a safe and accurate guide, no liability or responsibility can be accepted in this respect by the authors or publishers.

Typeset by Academic + Technical, Bristol

Printed and bound in Great Britain by MPG Books, Bodmin

Cover photograph

Lion Yard excavation showing a vertical concrete bored pile and horizontal steel props 


\section{Preface}

This book is divided into three parts - effectively three short courses focusing on the following three major geotechnical challenges of static soil-structure interaction problems:

- Part 1 Deep foundations - piles and barrettes

- Part 2 Multi-propped deep excavations

- Part 3 Bored and open-face tunnels below cities.

Part 1 Deep foundations - piles and barrettes concentrates on axially loaded long piles and barrettes. We were unable to include laterally loaded piles because of space limitations. The introductory sections of Part 1 draw mainly on the state-of-the-art papers by Poulos (1989) and Randolph and Wroth (1979). We then focus on the long piles that are typical in the Far East. Long piles have a particular character because their elastic shortening under load makes the pile head load-displacement test more difficult to interpret. Pile failure load criteria, therefore, need re-examining and we provide new displacement failure criteria based on many pile tests. For 'floating' barrettes and long piles, where their load capacity is derived from side resistance only, the degree of mobilisation of side resistance is clearly critical and so Mobilisation Rating is a key concept that is explained.

Part 2 Multi-propped deep excavations uses an extended case study as the vehicle for explaining the design concepts - this is Lion Yard, Cambridge. Preliminary design methods are presented as 'handwritten' Short Course Notes. Plastic mechanisms of failure are explained drawing on the work of Bolton (1993). Numerical modelling is used to obtain vertical and horizontal ground movements associated with the separate effects of panel trenching and installation (including bentonite support and tremie concreting), and of propping and excavating deep excavations retained by diaphragm walls. In particular, the realistic Wall-InstallationModelled (WIM) method is introduced and compared with the more common and unrealistic Wished-In-Place (WIP) method of analysis.

Part 3 Bored and open-face tunnelling below cities begins with an introduction from Bolton (1979) showing how easily soil arching supports 
tunnels - making sprayed concrete linings quite acceptable as used by the New Austrian Tunnelling Method (NATM). The main body of Part 3 draws extensively on the state-of-the-art paper by Mair and Taylor (1997) and concentrates on the evaluation of the surface settlement trough above a tunnel heading. The settlement trough shape follows the classic Gaussian probability curve - all that is required to define the trough are the parameters of either maximum settlement or ground loss, and the point of inflexion of the Gaussian curve. Numerical modelling is used to model the interaction between two parallel tunnels being driven with one lagging behind the heading of the other. The left and right tunnels are even driven in left and right drifts. This demonstrates the quite detailed and numerous installation steps that can be numerically modelled. We also show the effect of driving a tunnel near a pile tip. The pile capacity is first assessed by modelling an axial loading test and so providing a load-displacement curve from which a working load is found. A tunnel is driven near the tip of the pile where plastic yielding then occurs. The loss of working load is found to be an alarming twothirds!

Several detailed case studies are considered. These include a wellinstrumented test barrette in Hong Kong together with 15 other test barrettes, plus an extensive review of 28 large-diameter floating bored pile tests. These studies help to establish the Mobilisation Ratings that are critical in design. We also include the extended case studies of the Heathrow Express Trial Tunnel (Deane and Bassett, 1995) and the Lion Yard deep excavation ( $\mathrm{Ng}, 1992,1998)$. Finally, we briefly review the precautions taken to protect the Big Ben Clock Tower from ground movements caused by the Jubilee Line Extension tunnels (Burland et al., 2001). These measures included monitoring of the Tower tilt and compensation grouting by tubes à manchette (TAMs).

This book will give both student and practising civil engineers a useful review of the state-of-the-art of designing deep foundations, excavations and tunnels. In addition, the case studies and numerical modelling presented will give valuable insights into the challenges of soil-structure engineering.

Charles W. W. Ng, Noel Simons, Bruce Menzies

Hong Kong University of Science and Technology Hong Kong 2003 


\section{Acknowledgements}

We acknowledge permissions from authors and publishers to make verbatim extracts from their published works as follows:

Professor Braja Das and Brookes/Cole, Publishers, from:

- Das, B. M. (2000). Fundamentals of Geotechnical Engineering. Brookes/Cole, Thomson Learning.

Professor Harry Poulos and Thomas Telford, Publishers, from:

- Poulos, H. G. (1989). Twenty-ninth Rankine Lecture: Pile behaviour - theory and application. Géotechnique, 39(3), 363-415.

Professor Harry Poulos and John Wiley, Publishers, from:

- Poulos, H. G. and Davis, E. H. (1980): Pile Foundation Analysis and Design. John Wiley and Sons, New York.

Professor Mark Randolph and Thomas Telford, Publishers, from:

- Randolph, M. F. and Wroth, C. P. (1979). An analysis of the vertical deformation of pile groups. Géotechnique, 29(4), 423-439.

Mr Tommy Tomlinson and Prentice Hall, Publishers, from:

- Tomlinson, M. J. (2001). Foundation Design and Construction. 7th edn. Prentice Hall, London.

Professor Malcolm Bolton and M. D. and K. Bolton, Publishers, from:

- Bolton, M. D. (1979). A Guide to Soil Mechanics. M. D. and K. Bolton, Cambridge, 439 pp.

Professor Malcolm Bolton and the Japanese Society of Soil Mechanics and Foundation Engineering, Publishers, from:

- Bolton, M. D. (1993). Mechanisms of ground deformation due to excavation in clay. Excavation in Urban Areas, KIGForum '93, Toshihisha Adachi (ed.), Japanese Soc. of Soil Mech. and Fndn Engng, 1-33. 
Professors Robert Mair and Neil Taylor and (C) Swets \& Zeitlinger, Publishers, from:

- Mair, R. J. and Taylor, R. N. (1997). Theme lecture: Bored tunnelling in the urban environment. In Proc. 14th Int. Conf. Soil Mech. \& Fdn Engng, 4, 2353-2385, Balkema, Rotterdam.

Mr Tony Deane, Dr Dickie Bassett and Thomas Telford, Publishers, from:

- Deane, A. P. and Bassett, R. H. (1995). The Heathrow Express Trial Tunnel. Proc. Inst. Civ. Engrs, 113, July, 144-156.

Professor John Burland, Dr Jamie Standing, Mr Fin Jardine and Thomas Telford, Publishers, from:

- Burland, J. B., Standing, J. R. and Jardine, F. M., eds (2001). Building Response to Tunnelling. Thomas Telford, London.

Professors C. W. W. Ng and G. T. K. Lee and Elsevier, Publishers, from:

- $\quad \mathrm{Ng}, \mathrm{C} . \mathrm{W}$. W. and Lee, G. T. K. (2002). A three-dimensional parametric study of the use of soil nails for stabilising tunnel faces. Computers and Geotechnics, 29(8), 673-697.

Mr David Nash and Mr Martin Lings, University of Bristol and JT Design and Build, for:

- Photographs of Lion Yard, Cambridge.

The American Society of Civil Engineers, from:

- Ng, C. W. W., Yau, T. L. Y., Li, J. H. M. and Tang, W. H. (2001c). New failure load criterion for large diameter bored piles in weathered geomaterials. J. Geotech. \& Geoenv. Engng, ASCE, 127(6), 488-498, Tables 1-2, Figs 3, 4, 6.

- $\quad \mathrm{Ng}, \mathrm{C} . \mathrm{W}$. W. (1998). Observed performance of multi-propped excavation in stiff clay. J. Geotech. \& Geoenv. Engng, ASCE, 124(9), 889-905, Figs 1-23, Table 1.

- Ng, C. W. W. (1999). Stress paths in relation to deep excavations. J. Geotech. \& Geoenv. Engng, ASCE, 125(5), 357-363, Fig. 1.

- Ng, C. W. W. and Lei, G. H. (2003a). Performance of long rectangular barrettes in granitic saprolites. J. Geotech. \& Geoenv. Engng, ASCE, 129(8), 685-696, Figs 2-9, Tables 1-3.

- Ng, C. W. W. and Yan, W. M. (1998c). Stress transfer and deformation mechanisms around a diaphragm wall panel. J. Geotech. \& Geoenv. Engng, ASCE, 124(7), 638-648, Figs 1-15.

- Ng, C. W. W., Rigby, D., Ng, S. W. L and Lei, G. (2000b). Field studies of a well-instrumented barrette in Hong Kong. J. Geotech. \& Geoenv. Engng, ASCE, 126(1), 60-73, Figs 2-5, 7-9, 11-12. 
- Ng, C. W. W., Yau, T. L. Y., Li, J. H. M. and Tang, W. H. (2001a). Side resistance of large diameter bored piles socketed into decomposed rocks. J. Geotech. \& Geoenv. Engng, ASCE, 127(8), 642-657, Tables 2-4, Figs 2, 4, 7.

- Ng, C. W. W. and Lings, M. L. (1995). Effects of modelling soil nonlinearity and wall installation on back-analysis of deep excavation in stiff clay. J. Geotech. \& Geoenv. Engng, ASCE, 121(10), 687-695, Figs 3-14, Tables 1-2.

Professor Sam Paikowsky and A. A. Balkema Uigevers, from:

- Paikowsky, S. G. and Chernauskas, L. R. (1992). Energy approach for capacity evaluation of driven piles. Proc. 4th Conf. Application of Stress-wave Theory to Piles. (ed. F. B. I. Barends), Balkema, Rotterdam, pp. 595-601.

- Paikowsky, S. G. and Stenersen, K. L. (2000). The performance of the dynamic methods, their controlling parameters and deep foundation specifications. Keynote Lecture, Proc. 6th Int. Conf. Application of Stress-wave Theory to Piles, Niyama \& Beim (eds), Balkema, Rotterdam, pp. 281-304.

National Research Council of Canada from the Canadian Geotechnical Journal:

- Ng, C. W. W., Lee, K. M. and Tang, D. K. W. (2004). Threedimensional numerical investigations of new Austrian tunnelling method (NATM) twin tunnel interactions. Can. Geotech. J., 41, 523-539. 


\section{Dedication}

Professor Noel Simons FREng, 1931-2006

Noel Simons, who developed the University of Surrey into one of the UK's leading centres of geotechnical learning and research, and who inspired the Short Course Series of geotechnical books, died on August 10th 2006. He was aged 75.

He was not only a wonderful teacher, mentor, colleague and co-author, but was also a dear friend. This book is dedicated to his memory. 


\section{Contents}

$\begin{array}{ll}\text { Part 1: Deep foundations - piles and barrettes } & 1\end{array}$

Overview $\quad 2$

Sources 3

Chapter 1 Uses and types of piles and pile groups 5

$\begin{array}{ll}\text { Large-displacement piles } & 7\end{array}$

$\begin{array}{ll}\text { Small-displacement piles } & 10\end{array}$

$\begin{array}{ll}\text { Replacement piles } & 10\end{array}$

$\begin{array}{llr}\text { Chapter } 2 \text { Vertical pile load transfer mechanisms } & 15\end{array}$

$\begin{array}{ll}\text { Load-settlement relationships } & 15\end{array}$

Chapter 3 Failure load on piles: definitions, interpretation and criteria $\quad \mathbf{2 0}$

Definitions 20

$\begin{array}{ll}\text { Interpretation and criteria } & 21\end{array}$

$\begin{array}{lll}\text { Chapter } 4 & \begin{array}{l}\text { Establishment of a new failure load criterion for } \\ \text { large-diameter bored piles and barrettes }\end{array}\end{array}$

Overview: the problem of large-diameter, long bored piles 31

Method for establishing a new failure load criterion 34

Summary 39

$\begin{array}{lll}\text { Chapter } 5 & \text { Analysis, design and parameters } & \mathbf{4 0}\end{array}$

Categories of analysis/design procedures 40

Estimation of geotechnical parameters 40

Chapter 6 Dynamic formulae $\quad \mathbf{5 3}$

Overview 53

Pile-driving formulae $\quad 54$

The Wave Equation $\quad 59$

Reliability of dynamic methods $\quad 62$ 
Research and practice in North America 64

Research and practice in Australia 65

Design practice in Hong Kong 66

$\begin{array}{lll}\text { Chapter } 8 & \text { Case studies: rock-socketed piles } & 68\end{array}$

Overview 68

Displacement Index (DI) 73

Capacity of side resistance and relationship with UCS and $\begin{array}{ll}\text { decomposition grade } & 73\end{array}$

Chapter 9 Pile instrumentation: a case study of a well-instrumented barrette in Kowloon Bay, Hong Kong 77

Overview: key questions $\quad 77$

Introduction $\quad 77$

$\begin{array}{ll}\text { Site location and ground conditions } & 78\end{array}$

Details of construction $\quad 78$

Instrumentation $\quad 80$

Load and displacement behaviour of barrette $\quad 82$

Barrette side resistance 83

Pore pressure response at soil-barrette interface $\quad 85$

Changes of lateral stress at soil-barrette interface 87

Chapter 10 Case studies: 15 full-scale loading tests on barrettes in Hong Kong $\quad 89$

Test barrettes reviewed $\quad 89$

Site locations and ground conditions $\quad 89$

Methods of interpretation of test data 89

Mobilization of side resistance in granitic saprolites 94

$\begin{array}{ll}\text { Construction effects on side resistance } & 100\end{array}$

Chapter 11 Case studies: bored piles in weathered materials in $\begin{array}{ll}\text { Hong Kong } & 102\end{array}$

Overview: key questions 102

Introduction $\quad 102$

Typical ground conditions and soil types in Hong Kong 103

Load test procedures 103

Load tests under review 104

Degree of mobilization of side shear resistance 109

Correlation of side shear resistance with SPT 109

Construction factor 113 
Overview: methods of analysis

Empirical methods

Simplified analytical methods

Numerical methods

Settlement characteristics of piles and pile groups using the boundary-element method

Part $1 \quad$ Summary

Part 2: Multi-propped deep excavations

Overview

Sources

Chapter 13 Stress paths in relation to a deep excavation

Chapter 14 Plastic geo-structural analysis

Source

Overview

Plastic geo-structural mechanism for lateral stress relief on an undrained clay face

Mechanism for undrained excavation against a cantilever wall pinned at its toe

Geo-structural mechanism for base heave in undrained clay excavations

\section{Chapter 15 Preliminary design for deep excavations} (short course notes)

Preliminary design for ultimate limit states

Design against base heave in clays

Design against piping in sands

Preliminary design for serviceability limit states

Estimation of ground settlements outside excavations and maximum lateral wall deformations

Estimation of soil swelling inside the excavation in both the short term and long term

Comment: detailed design using computer programs 
Chapter 16 Instrumentation: a case study of a multi-propped excavation at Lion Yard, Cambridge

Overview: the site 167

$\begin{array}{ll}\text { Geology } & 167\end{array}$

$\begin{array}{lr}\text { Soil profile and properties } & 169\end{array}$

$\begin{array}{lr}\text { Top-down construction } & 173\end{array}$

$\begin{array}{ll}\text { Unusual research opportunities } & 175\end{array}$

$\begin{array}{ll}\text { Observed performance } & 179\end{array}$

General ground deformation patterns 184

Assessment: the 'two-phase' behaviour of Gault Clay 194

Concluding comments 196

Chapter 17 Lateral pressure of wet concrete in diaphragm walls 198

$\begin{array}{ll}\text { Overview } & 198\end{array}$

$\begin{array}{ll}\text { Pressure of wet concrete on formwork } & 199\end{array}$

Underwater concreting and diaphragm wall construction 202

The Lion Yard diaphragm wall 204

$\begin{array}{ll}\text { The Telefonhuset, Oslo } & 209\end{array}$

$\begin{array}{ll}\text { The Seville subway } & 211\end{array}$

$\begin{array}{ll}\text { Assessment } & 213\end{array}$

$\begin{array}{ll}\text { Concluding comments } & 217\end{array}$

Chapter 18 Stress transfer and deformation mechanisms around $\begin{array}{ll}\text { diaphragm walls } & 218\end{array}$

Overview 218

$\begin{array}{ll}\text { Numerical models and parameters } & 220\end{array}$

Finite-difference mesh and modelling procedure 221

$\begin{array}{ll}\text { Normal stress distributions behind panel } & 224\end{array}$

Shear stress distributions behind panel 229

Horizontal deformations $\quad 235$

$\begin{array}{ll}\text { Surface settlements } & 236\end{array}$

Assessment 237

$\begin{array}{ll}\text { Concluding comments } & 239\end{array}$

Chapter 19 Effects of modelling soil non-linearity and wall installation on back-analysis of deep excavations in stiff clay 241

$\begin{array}{ll}\text { Overview } & 241\end{array}$

$\begin{array}{ll}\text { Numerical analysis } & 241\end{array}$

$\begin{array}{ll}\text { Simulation procedures } & 245\end{array}$

Comparison of linear and non-linear analyses with

Wall-Installation-Modelled (WIM) 247 
Chapter 20 Comparison of Wall-Installation-Modelled (WIM) and

Wished-In-Place (WIP) analyses with Mohr-Coulomb model

Overview

Assessment of mobilized soil stiffness

Concluding comments

Chapter 21 Prediction of ground movements due to diaphragm wall installation

Overview

Elastic solutions

Modelling diaphragm wall installation: methodology

Ground deformations

Assessment

Chapter 22 The prediction and control of displacements around deep excavations in completely decomposed granite

Minimizing displacements

Prediction of displacements

Assessment

Part 2

Summary

Part 3: Bored and open-face tunnelling below cities

Overview

Sources

Terminology

Chapter 23 Unsupported tunnels: theoretical assessment of the collapse of soil arches

Chapter 24 Modern tunnel construction techniques

Chapter 25 Principal design and construction requirements 
Chapter 27 Finite-element modelling of multi-tunnel interactions and tunnelling effects on adjacent piles

Overview

Influence of in situ stress state and anisotropy

Multi-tunnel interaction

Stabilizing tunnel faces using soil nails

Finite-element modelling of a tunnel advancing on an existing loaded pile

Chapter 28 Effect of ground movements on buildings

Chapter 29 Case study: effect of the Jubilee Line Extension on the Big Ben Clock Tower

Recommended list of units, unit abbreviations, quantity symbols and conversion factors for use in soil and rock mechanics 